The Purposes of Paradise 



\title{
The Purposes of Paradise
}

U.S. Tourism and Empire in Cuba and Hawai' $i$

\section{Christine Skwiot}

\author{
$\overline{\text { PENN }}$ \\ UNIVERSITY OF PENNSYLVANIA PRESS \\ PHILADELPHIA · OXFORD
}


Copyright (C) 2010 University of Pennsylvania Press

All rights reserved. Except for brief quotations used for purposes of review or scholarly citation, none of this book may be reproduced in any form by any means without written permission from the publisher.

Published by

University of Pennsylvania Press

Philadelphia, Pennsylvania 19104-4112

Printed in the United States of America on acid-free paper 109876654321

\section{Library of Congress Cataloging-in-Publication Data}

Skwiot, Christine.

The purposes of paradise : U.S. tourism and empire in Cuba and Hawai'i / Christine Skwiot.

p. $\mathrm{cm}$.

Includes bibliographical references and index.

ISBN 978-0-8122-4244-7 (hardcover : alk. paper)

1. Tourism-Political aspects-Cuba-History-19th

century. 2. Tourism-Political

aspects-Cuba-History-20th century.

3. Tourism-Political aspects-Hawaii-History-19th

century. 4. Tourism-Political

aspects-Hawaii-History-20th century.

5. Cuba-Colonization. 6. Hawaii-Colonization.

7. United States-Territorial expansion. 8. United

States-Foreign relations-19th century. 9. United

States-Foreign relations-20th century.

10. Imperialism-History. I. Title.

G155.C9S56 2010

$306.20973-\mathrm{dc} 22$

2010004927 
For Larry 
